\title{
KONSOLIDASI TANAH UNTUK OPTIMALISASI TANAH PERTANIAN BERSKALA KECIL (STUDI KASUS DI KOTA SALATIGA)
}

\author{
Hadi Arnowo \\ Pusat Pengembangan Sumber Daya Manusia (PPSDM) Kementerian ATR/ BPN, Jl. Akses \\ Tol Cimanggis, Cikeas Udik, Gunung Putri, Kabupaten Bogor 16966 \\ Koresponden email: h_arnowo@yahoo.com
}

Naskah diterima: 30 Agustus 2021; revisi: 17 September 2021; disetujui: 10 Januari 2022

\begin{abstract}
The implementation of land consolidation in the city of Salatiga in the 2018 fiscal year is located in the Kauman Kidul Village. The purpose of this research is to examine the benefits of soil for optimizing small consolidated agricultural land. The research method used is the descriptive qualitative method, namely explaining what is obtained and analyzing it with regulations regarding land consolidation. The type of data used is primary data sourced from interviews and observations and secondary data in the form of textual data and spatial data from the Land Office of Salatiga City. The agreement from the participants of the land consolidation program that the main contribution of land for development is in the form of widening and construction of environmental roads as well as technical improvement of irrigation networks. While the remaining donations are in the form of land used for agro-tourism development such as culinary centers and rest areas, security posts, shared cattle pens, parking areas, gazebos, and reservoirs. The implementation of the land consolidation design in the field did not experience obstacles because it was by the wishes of the community. The positive impact of implementing land consolidation is that farming communities are offered to build agricultural fields and at the same time agro-tourism that involves community participation.
\end{abstract}

Keywords: Agrotourism, Infrastructure, Sustainable Development

\begin{abstract}
Abstrak: Pelaksanaan konsolidasi tanah di Kota Salatiga pada tahun anggaran 2018 terletak di Kelurahan Kauman Kidul. Tujuan dari penelitian ini adalah mengkaji manfaat konsolidasi tanah untuk optimalisasi tanah pertanian berskala kecil. Metode penelitian yang digunakan adalah metode kualitatif deskriptif yaitu menjelaskan hasil yang diperoleh dan menganalisisnya dengan peraturan mengenai konsolidasi tanah. Jenis data yang digunakan adalah data primer yang bersumber dari wawancara dan observasi dan data sekunder berupa data tekstual dan data spasial dari Kantor Pertanahan Kota Salatiga. Kesepakatan dari peserta program konsolidasi tanah bahwa sumbangan tanah untuk pembangunan yang utama berupa pelebaran dan pembangunan jalan lingkungan serta peningkatan teknis jaringan irigasi. Sedangkan hasil sumbangan yang masih tersisa berupa persil tanah digunakan untuk pembangunan penunjang agrowisata seperti pusat kuliner dan tempat istirahat, pos pengamanan, kandang ternak bersama, area parkir, gazebo dan embung. Implementasi desain konsolidasi tanah di lapangan tidak mengalami hambatan karena sudah sesuai dengan kehendak masyarakat. Dampak positif dari terlaksananya konsolidasi tanah adalah masyarakat petani termotivasi untuk tetap mengusahakan lahan pertanian dan sekaligus membangun agrowisata yang melibatkan partisipasi masyarakat.
\end{abstract}

Kata Kunci: Agrowisata, Infrastruktur, Pembangunan Berkelanjutan 


\section{Hadi Arnowo}

\section{A. Pendahuluan}

Konsolidasi tanah menurut fungsi dan peruntukan kawasan terdiri dari konsolidasi tanah pertanian dan konsolidasi tanah non pertanian. Menurut Pasal 1 Peraturan Menteri ATR/ Kepala BPN No. 12 Tahun 2019 tentang Konsolidasi Tanah pengertian konsolidasi tanah pertanian adalah konsolidasi tanah yang dilakukan pada tanah-tanah pertanian yang berada di kawasan perdesaan. Sedangkan konsolidasi tanah non-pertanian adalah konsolidasi tanah yang dilakukan pada tanah non-pertanian, termasuk penyediaan tanah bagi pembangunan untuk kepentingan umum di kawasan perkotaan dan semi perkotaan.

Konsolidasi tanah adalah salah satu instrumen pengelolaan pertanahan yang menata penguasaan, pemilikan dan pemanfaatan tanah dengan tujuan meningkatkan efisiensi dan produktivitas tanah, pemanfaatan ruang serta kualitas lingkungan hidup (Prabowo, 2017). Secara umum konsolidasi tanah di wilayah perkotaan adalah didominasi untuk penataan wilayah pemukiman padat (Wijaya et al., 2016). Meskipun wilayah perkotaan didominasi oleh daerah terbangun, tetapi tanah pertanian tanaman pangan masih tetap diperlukan sebagai bagian dari strategi ketahanan pangan (Chandra \& Diehl, 2019) dan pendukung untuk mewujudkan ketahanan pangan sekaligus pengentasan kemiskinan di perkotaan (Fauzi et al., 2016). Tanah pertanian tanaman pangan khususnya sawah menunjukkan tren ke arah kepemilikan yang semakin sempit yang berimplikasi pada kesejahteraan masyarakat petani yang semakin menurun (Winarso, 2012). Kondisi penguasaan tanah sawah yang semakin terfragmentasi dan pentingnya mempertahankan penggunaan tanah sawah menjadi dasar dari pelaksanaan konsolidasi tanah pertanian di wilayah perkotaan yang dapat dikombinasikan dengan tanah pemukiman.

Rencana konsolidasi tanah di Kota Salatiga adalah berdasarkan pertimbangan dari kegiatan Potensi Objek Konsolidasi Tanah tahun 2016 yang dilakukan oleh Kanwil BPN Provinsi Jawa Tengah. Arahan potensi konsolidasi tanah di Kota Salatiga meliputi pengembangan wilayah, peremajaan kota, optimalisasi dan areal pengembang lainnya. Salah satu lokasi arahan yang dapat dilaksanakan konsolidasi tanah adalah di kelurahan Kauman Kidul, Kecamatan Sidorejo. Arahan yang dijadikan landasan pelaksanaan konsolidasi tanah adalah peremajaan kota untuk pertanian dan non pertanian. dengan pertimbangan terdapat pemukiman padat penduduk dan kerapatan bangunan yang tinggi serta cenderung menjadi kawasan kumuh (Kanwil BPN Provinsi Jawa Tengah, 2016)

Pertimbangan lain untuk pelaksanaan konsolidasi tanah di lokasi tersebut di atas adalah kondisi penggunaan tanah pertanian yang luas sehingga perlu dioptimalkan untuk mencegah alih fungsi lahan (Kanwil BPN Provinsi Jawa Tengah, 2017) dan untuk menerapkan konsep agrowisata (Kanwil BPN Provinsi Jawa Tengah, 2018). 
Perencanaan konsolidasi tanah menyangkut letak lokasi harus memenuhi kesesuaian dengan Rencana Tata Ruang Wilayah Kota Salatiga yang ditetapkan berdasarkan Peraturan Daerah Kota Salatiga Nomor 4 Tahun 2011. Tanah-tanah dengan penggunaan tanah sawah tetap dipertahankan keberadaannya yaitu untuk tujuan pertanian tanaman pangan. Dengan demikian lokasi yang diarahkan untuk konsolidasi tanah pada tanah-tanah sawah secara fungsional tergolong konsolidasi tanah pertanian. Pelaksanaan konsolidasi tanah pertanian di wilayah kota tidak menjadi masalah sepanjang sesuai dengan rencana tata ruang wilayah. Hasil yang diperoleh dari konsolidasi tanah perkotaan adalah terciptanya penggunaan tanah yang sesuai dengan prinsip aman, tertib, lancar, dan sehat (ATLAS) serta lingkungan yang tertata (Ariyani \& Parsa, 2019).

Masalah yang diidentifikasi terkait dengan penyelenggaraan konsolidasi tanah adalah bagaimana praktik penyelenggaraan kegiatan konsolidasi tanah? dan bagaimana konsep desain konsolidasi tanah untuk optimalisasi tanah pertanian berskala kecil milik masyarakat?

Konsolidasi tanah memberikan manfaat kepada petani menurut Ekowati et al. (2020), Bawono (2018), dan Du et al (2018) yaitu melalui terwujudnya corporate farming (usaha tani korporasi) yang efisien dan berdampak pada peningkatan produktivitas hasil usaha tani. Li et al. (2018) menambahkan adanya peningkatan hubungan antara manusia dan tanah melalui peningkatan skala usaha. Menurut Pasaribu \& Istriningsih (2020), para petani akan semakin banyak yang menerima konsolidasi tanah melalui sosialisasi dari pemerintah.. Studi konsolidasi tanah dengan aspek yang berbeda dikemukakan oleh Pratama (2020) yaitu konsolidasi di wilayah perkotaan dapat dilaksanakan secara optimal dengan sistem sukarela dan sistem wajib. Secara prinsip konsolidasi tanah akan mewujudkan kondisi wilayah yang tertata dengan memperhatikan kondisi lingkungan serta aspirasi masyarakat (Wijaya et al., 2016).

\section{B. Metode Penelitian}

Penelitian ini menggunakan metode kualitatif yaitu penulis menggunakan data primer dan data sekunder. Data primer diperoleh dari wawancara dan observasi lapang. Wawancara dilakukan kepada petugas kelurahan dan ketua kelompok tani yang berperan secara langsung dalam kegiatan konsolidasi tanah. Bentuk wawancara berupa pertanyaan terbuka terkait dengan penyelenggaraan konsolidasi tanah. Sedangkan observasi yang dilakukan penulis berupa pengamatan terhadap hasil konsolidasi tanah secara langsung. Data sekunder yang diperoleh dari penelitian ini berupa laporan kegiatan yang terdiri dari Potensi Objek Konsolidasi Tanah Kota Salatiga Provinsi Jawa Tengah Tahun 2016, Laporan Konsolidasi Tanah Kota Salatiga Tahun 2017 dan Laporan Konsolidasi Tanah Kota Salatiga 


\section{Hadi Arnowo}

Tahun 2018. Lokasi kegiatan konsolidasi tanah dapat dilihat pada Gambar 1. di bawah ini. Data primer dan sekunder tersebut di atas kemudian diklasifikasikan dalam tahapan kegiatan konsolidasi tanah. Selanjutnya hasil kegiatan tersebut dideskripsikan dan dianalisis untuk dikaitkan dengan tujuan penelitian ini.

Gambar 1. Peta Situasi Lokasi Konsolidasi Tanah

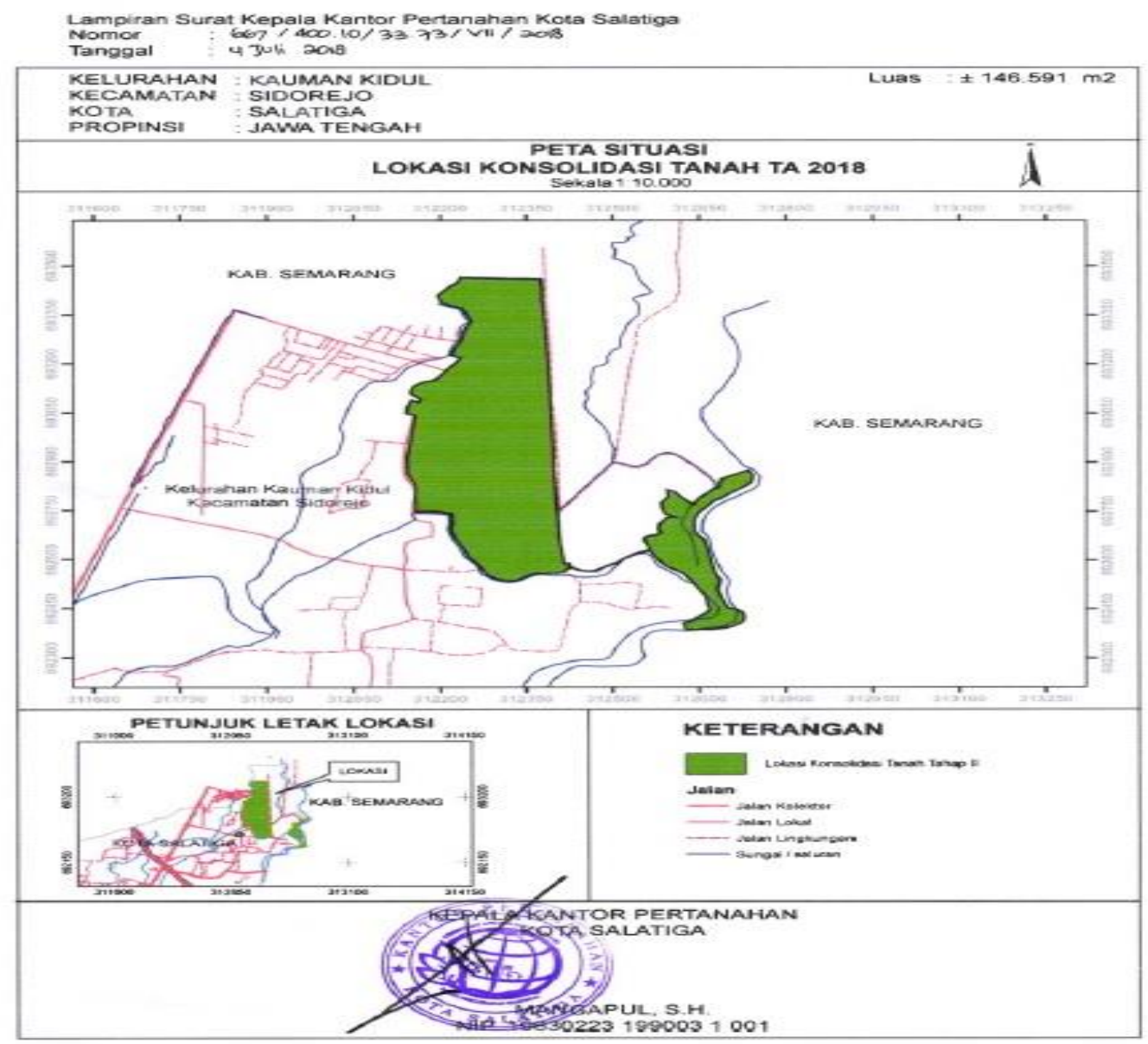

Sumber: Laporan Kegiatan Konsolidasi Tanah Tahun 2018

\section{Penyelenggaraan Konsolidasi Tanah}

\section{Pemilihan Lokasi}

Kelurahan Kauman Kidul yang berada di Kecamatan Sidorejo, memiliki luas wilayah kurang lebih 195.849 ha. Jumlah penduduk berkisar 3.639 jiwa dengan kepala keluarga sebanyak 987 KK. Mata pencaharian penduduk Kelurahan Kauman Kidul sebagian besar mengandalkan pada pertanian. Berdasarkan data dari Daftar Subjek Dan Objek Konsolidasi Tanah, rata-rata bidang tanah pertanian di bawah $1.000 \mathrm{~m} 2$ yang umumnya berupa sawah dan sisanya adalah lahan kering. Meskipun ukuran bidang tanah sawah relatif kecil tetapi intensitas pertanaman padi adalah $2 \times$ setahun. 
Letak lokasi konsolidasi tanah di Desa Kauman Kidul, Kecamatan Sidorejo, Kota Salatiga. Pelaksanaan konsolidasi tanah terbagi atas 2 tahap. Tahap I tahun 2017 sebanyak 115 bidang untuk 115 orang dengan total luas areal $152.948 \mathrm{~m} 2$. Sedangkan tahap II tahun 2018 sebanyak 157 bidang untuk 128 orang dengan total luas areal $146.591 \mathrm{~m} 2$. Pemilihan lokasi konsolidasi tanah tersebut adalah berdasarkan kajian Potensi Objek Konsolidasi Tanah yang dilakukan pada tahun 2016 yaitu 1 tahun sebelum pelaksanaan konsolidasi tanah.

Pemilihan lokasi berdasarkan Potensi Objek Konsolidasi Tanah (POKT) adalah dengan membuat peta indikasi potensi obyek konsolidasi tanah melalui teknik tumpang susun (overlay) antara peta administrasi, peta penggunaan tanah dan peta rencana pola ruang untuk menghasilkan Peta Kesesuaian Potensi. Hasil dari overlay peta-peta tersebut adalah titik-titik terindikasi potensi obyek konsolidasi tanah pertanian maupun non pertanian. Selanjutnya dilakukan survei lapang untuk menentukan lokasi terpilih untuk kegiatan konsolidasi tanah. Berdasarkan kajian yang meliputi karakteristik fisik wilayah dan kondisi sosial ekonomi masyarakat, Kota Salatiga memiliki potensi kegiatan konsolidasi tanah.

\section{Persiapan Kegiatan}

Kegiatan Konsolidasi Tanah di Kota Salatiga pada tahun 2017 dan 2018 mengacu Peraturan Kepala BPN Nomor 4 Tahun 1991 tentang Konsolidasi Tanah yang terdiri dari Pemilihan Lokasi, Pengorganisasian dan Bimbingan Masyarakat, Penjajakan Kesepakatan, Pengukuran dan Pemetaan Keliling, Penetapan Lokasi, Identifikasi Subyek dan Obyek, Pengukuran dan Pemetaan Rincikan, Pengukuran dan Pemetaan Topografi dan Pemetaan Penggunaan Tanah, Penyusunan Rencana Blok Plan, Penyusunan Desain Konsolidasi Tanah, Musyawarah Rencana Penataan Kaveling Baru, Pelepasan Hak Atas Tanah dan Penegasan Tanah Obyek Konsolidasi Tanah, Pemindahan Desain Konsolidasi Tanah ke Lapang (Stacking Out), Penerbitan SK Pemberian Hak/Pengesahan Data Fisik dan Yuridis dan Pembukuan Hak dan Penerbitan Sertipikat. Di dalam pelaksanaan konsolidasi tanah pada tahun 2018 masih menggunakan Peraturan Kepala Badan Pertanahan Nasional Nomor 4 Tahun 1991 tentang Konsolidasi Tanah.

Setelah penetapan lokasi konsolidasi tanah melalui POKT dilakukan pemantapan pilihan lokasi melalui tinjauan lapang dan penjajakan kesediaan masyarakat untuk mengikuti konsolidasi tanah. Kondisi wilayah Kelurahan Kauman Kidul yang umumnya tanah pertanian dan pemukiman petani yang mengelompok dapat diterapkan konsep konsolidasi tanah. Atas dasar pertimbangan tersebut dilakukan langkah-langkah persiapan. 
Langkah-langkah persiapan yang dilakukan oleh Kantor Pertanahan Kota Salatiga meliputi: 1) pemilihan lokasi; 2) pengorganisasian dan bimbingan masyarakat; 3) penjajakan kesepakatan; 4) pengukuran dan pemetaan keliling; 5) penetapan lokasi. Lokasi konsolidasi tanah pada tahun 2017 berada pada wilayah Kelurahan Kauman Kidul. Target objek konsolidasi tanah sebanyak 115 bidang yang merupakan tanah hak milik ada 71 bidang, tanah yasan 42 bidang dan Tanah negara sebanyak 2 bidang dengan total luas keseluruhan $152.948 \mathrm{~m}^{2}$. Tanah negara yang ada masih dalam penguasaan Pemerintah Kota Salatiga cq. Kelurahan Kauman Kidul. Pelaksanaan kegiatan Konsolidasi Tanah melibatkan masyarakat dengan tingkat Partisipasi 100\%. Hal ini menunjukkan bahwa setuju dan antusias untuk dilakukan penataan melalui Konsolidasi tanah. Masyarakat menyadari bahwa pentingnya jaminan kepastian hukum akan tanah yang dimilikinya dengan diperoleh sertifikat. Selain itu dapat merasakan manfaat lain seperti dapat menikmati fasilitas lain yang dibangun seperti jalan, saluran air, dan sebagainya.

Beberapa sub kegiatan sebagai bentuk persiapan pelaksanaan konsolidasi tanah berikut ini:

1. Membentuk SK Tim Penyelenggara Konsolidasi tanah. Tim Koordinasi dibentuk dan ditetapkan dengan surat keputusan Walikota Kota Salatiga. Adapun SK Tim penyelenggara yang telah ditetapkan Nomor 590/05/344/2017 tanggal 20 April 2017.

2. Menerbitkan SK Lokasi Pelaksanaan Konsolidasi Tanah. Adapun SK Lokasi Pelaksanaan Konsolidasi Tanah yang telah ditetapkan Walikota Salatiga Nomor 591/588/2017 tanggal 6 November 2017.

3. Pembuatan Rencana Desain

Untuk mendukung awal koordinasi dengan pemerintah daerah dan penjajakan dengan masyarakat, perlu disusun Skets Blok Plan. Skets Blok Plan harus mengacu pada rencana Tata Ruang Wilayah yang sudah ditetapkan menjadi peraturan daerah. Sebenarnya secara keseluruhan terdapat \pm 278 bidang tanah siap untuk dilaksanakan konsolidasi tanah. Mengingat terbatasnya anggaran untuk pembiayaan kegiatan, maka untuk tahap awal hanya untuk 115 bidang. Sedangkan sisa bidang dilaksanakan pada tahun anggaran 2018. Tahap pengumpulan data meliputi Pengumpulan data fisik (Pengukuran rincikan) dan Pengumpulan data yuridis. Pengumpulan data yuridis menggunakan formulir KT-4313 dan hasil pengumpulan data identifikasi subyek dan obyek peserta konsolidasi tanah dituangkan dalam Form KT-4315. 
Gambar 2. Desain Konsolidasi Tanah

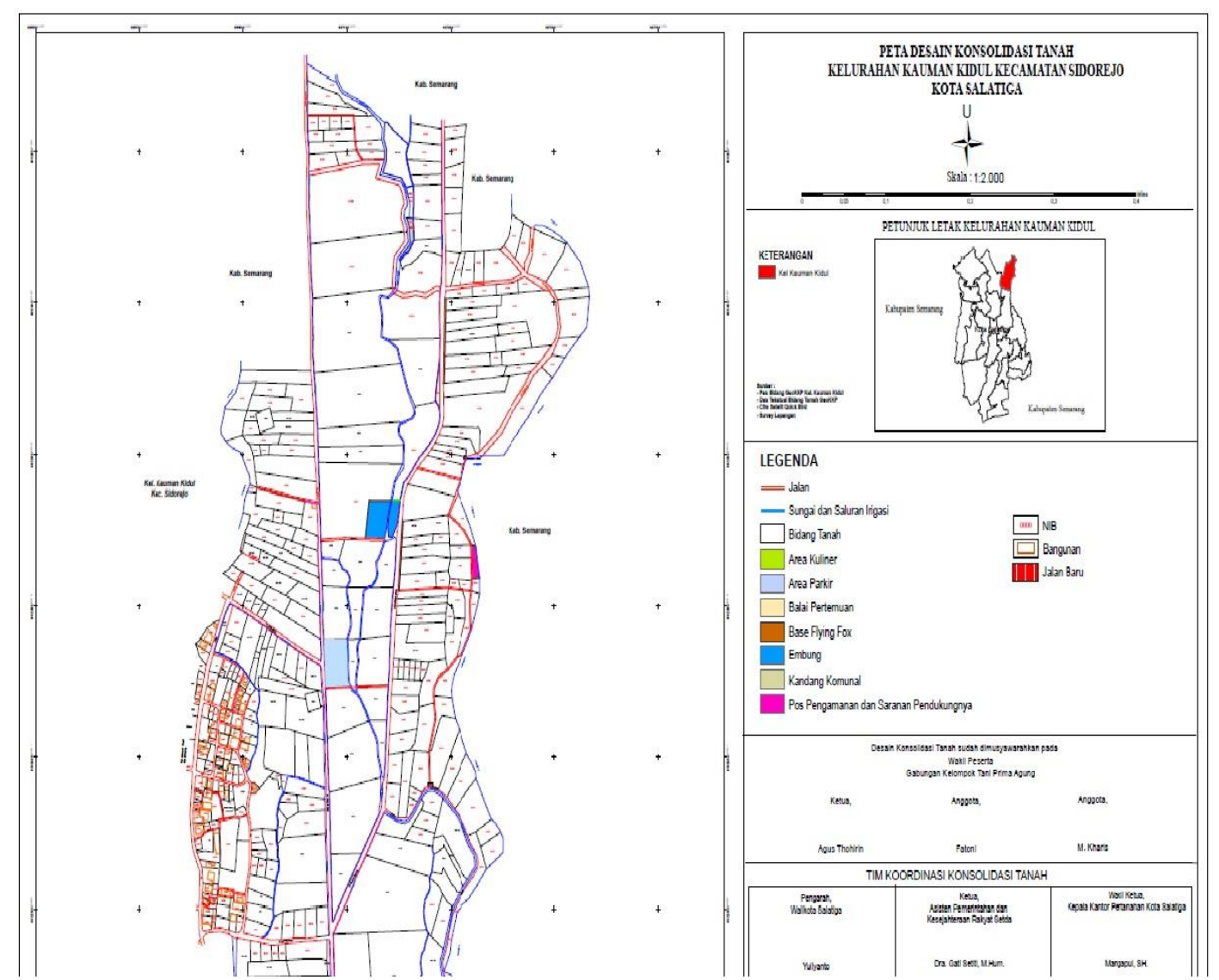

Sumber: Laporan Kegiatan Konsolidasi Tanah Tahun 2017

Bentuk desain bidang tanah berdasarkan gambar di atas sudah menunjukkan pola teratur dengan luas bidang tanah yang beragam. Secara umum pembuatan desain konsolidasi tanah menata tanah menjadi teratur baik bentuk maupun tata letaknya dilakukan melalui cara penggeseran letak, penggabungan, pemecahan, penukaran, penataan, penghapusan dan pengubahan. Selain itu terdapat penggeseran batas bidang tanah yang dibuat jalan lingkungan atau pelebaran jalan desa. Selain itu penataan letak dan bentuk disertai dengan penerapan

Pengaturan bentuk bidang tersebut diatas dilengkapi prasarana dan fasilitas yang diperlukan seperti jalan, jalur hijau dan sebagainya sehingga menghasilkan pemanfaatan tanah yang optimal dan memenuhi berbagai persyaratan. Desain yang dibuat tidak merubah lokasi bidang tanah, hanya mengambil sebagian dari bidang tanah yang akan dilalui Pengaturan tersebut dituangkan dalam bentuk Peta Desain Konsolidasi Tanah. Peta yang telah disahkan akan dilanjutkan dengan kegiatan staking-out dan pekerjaan konstruksi. Pembuatan desain yang memiliki konsep yang sama adalah konsolidasi tanah melalui revitalisasi kawasan kumuh di Desa Kurau, Kabupaten Bangka Tengah. Menurut (Yurmansah \& Mussadun, 2016) pembuatan desainnya adalah dengan pengurangan 


\section{Hadi Arnowo}

bagian persil tanah untuk infrastruktur dengan mempertimbangkan luas kepemilikan rumah. bangunan.

Dasar pembuatan desain konsolidasi tanah adalah dari hasil pengukuran dan pemetaan bidang tanah eksisting kemudian dibuatkan desain posisi bidang tanah, infrastruktur dan sumbangan tanah untuk keperluan masyarakat. Mengingat cukup padatnya pemukiman dan tanah pertanian berukuran kecil tetapi menjadi tumpuan mata pencaharian, maka tanah yang dikonsolidasikan tidak merubah posisi. Perubahan yang terjadi karena adanya rencana pembuatan jalan lingkungan dan pelebaran jalan desa. Disini para pemilik tanah yang terkena rencana pembangunan tersebut merelakan pelepasan sebagian luas tanah untuk rencana pembangunan tersebut.

Penyusunan desain konsolidasi tanah berdasar pada hasil kesepakatan antara peserta dan pelaksana konsolidasi tanah. Desain Konsolidasi Tanah di desa Kauman Kidul kecamatan Sidorejo sangat jauh berbeda dengan kondisi awalnya. Desain ini disesuaikan dengan konsep agrowisata yang akan dibangun. Musyawarah antara peserta dan pelaksana konsolidasi tanah telah dilaksanakan pada tanggal 11 Desember 2017 dan dihasilkan kesepakatan yang dituangkan ke dalam berita acara kesepakatan hasil desain yang ditandatangani oleh tim pelaksana.

4. Musyawarah Penerapan Desain

Pelaksanaan musyawarah dengan peserta konsolidasi tanah membahas hal-hal sebagai berikut:

a) Prinsipnya pelaksanaan konsolidasi tanah dibiayai oleh pemilik tanah, dengan demikian maka konsolidasi tanah sekaligus merupakan wahana partisipasi aktif masyarakat dalam pembangunan

b) Dalam hal musyawarah untuk penetapan lokasi Konsolidasi tanah dapat dilaksanakan apabila sekurang-kurangnya 85\% dari luas seluruh areal tanah yang akan dikonsolidasikan, menyatakan persetujuannya (berdasarkan Peraturan Ka BPN No. 4 Tahun 1991 tentang Konsolidasi Tanah)

c) Dalam hal musyawarah untuk mencapai kesepakatan mengenai sumbangan, antara lain untuk menjelaskan bahwa Sumbangan tanah untuk pembangunan adalah bagian dari obyek Konsolidasi tanah yang disediakan untuk pembangunan prasarana jalan dan fasilitas umum lainnya, serta untuk tanah biaya pengganti biaya pelaksanaan. dengan harapan dapat menghasilkan kesepakatan Sumbangan Wajib Untuk Tanah Pembangunan (SWTP). 
d) Sistem yang lazim digunakan dalam penetapan besarnya SWTP adalah berdasarkan perhitungan luas; berdasarkan perhitungan Nilai/harga tanah dan berdasarkan perhitungan campuran antar luas tanah dengan harga tanah.

Keberhasilan musyawarah tersebut di atas sangat ditentukan oleh efektivitas sosialisasi mengenai konsolidasi tanah oleh tim penyuluh. Hal ini senada dengan pendapat dari (Siregar, 2013) yang menyebutkan bahwa kesediaan masyarakat di wilayah kota dipengaruhi oleh adanya jaminan dari pemerintah tidak menggusur dan mendapat kepastian tempat tinggal serta memperoleh sertipikat hak atas tanah.

Meskipun kegiatan konsolidasi telah diatur menurut petunjuk teknis, tetapi potensi kegagalan pelaksanaan konsolidasi tanah tetap ada. Penyebab terbesar kegagalan konsolidasi tanah menurut (Ishak et al., 2011) menyebutkan bahwa kegagalan konsolidasi tanah karena ketiadaan dokumen legal menyangkut status tanah, kurangnya partisipasi penduduk, dan lemahnya peran pemerintah. Sebaliknya apabila instansi penyelenggara konsolidasi tanah dapat mengajak partisipasi masyarakat dengan baik, maka konsolidasi tanah akan berjalan sesuai dengan tujuan. Bentuk partisipasi masyarakat dalam konsolidasi tanah berupa kesepakatan untuk mengikuti konsolidasi tanah, kesediaan untuk menyisihkan bagian dari tanahnya sebagai Sumbangan Tanah Untuk Pembangunan (STUP) yang dibangun fasilitas umum dan sosial serta untuk pembiayaan pelaksanaan konsolidasi tanah (Candrakirana et al., 2014).

Penetapan SWTP adalah berdasarkan: Pertama, perhitungan luas dalam bentuk tanah. Dalam rangka pelaksanaan penataan penguasaan dan penggunaan tanah obyek konsolidasi tanah, para peserta menyerahkan sebagian tanahnya sebagai sumbangan tanah untuk pembangunan yang akan dipergunakan untuk pembangunan prasarana jalan dan fasilitas umum lainnya dan pembiayaan pelaksanaan konsolidasi tanah. Besarnya sumbangan tanah untuk pembangunan, ditetapkan berdasarkan kesepakatan bersama peserta konsolidasi tanah dengan mengacu kepada rencana tata ruang.

Kedua, perhitungan nilai/harga tanah dalam bentuk uang antara lain apabila peserta konsolidasi hanya mempunyai tanah dalam luasan yang terlalu kecil, sehingga tidak mungkin menyerahkan sebagian tanahnya sebagai sumbangan tanah untuk pembangunan. Maka dapat mengganti sumbangan tersebut dengan uang atau bentuk lainnya yang disetujui bersama oleh para peserta konsolidasi. Ketiga, berdasarkan perhitungan campuran antar luas tanah dengan harga tanah. Dihitung biaya pematangan tanah secara gotong royong, dibandingkan harga tanah per meter persegi, sehingga masing-masing bidang tanah dibebankan biaya pematangan tanah sesuai luas. 
Berdasarkan wawancara dengan ketua Gapoktan (Gabungan Kelompok Tani), Agus Thohirin, mengenai jalannya musyawarah berjalan dengan lancar. Hal ini karena sebelum pelaksanaan konsolidasi tanah, masyarakat telah mendapatkan sosialisasi sehingga mereka memahami dan antusias untuk melaksanakan kegiatan konsolidasi tanah. Selain itu di dalam desain konsolidasi tanah tidak merubah banyak mengenai posisi dan luasan bidang tanah masyarakat.

Penerapan desain konsolidasi tanah adalah berdasarkan peta desain konsolidasi tanah yang telah disepakati. Petugas melakukan pekerjaan staking out atau penerapan titiktitik batas bidang tanah di lapangan. Menurut penjelasan dari petugas lapangan dari Kantor Pertanahan Kota Salatiga, bahwa penerapan titik-titik di lapangan tersebut disertai dengan pemasangan patok batas. Pemasangan patok dari pekerjaan staking out tersebut disaksikan oleh pemilik tanah dan tetangga yang berbatasan beserta aparat desa.

5. Pelepasan Hak Atas Tanah

Pelepasan Hak atas tanah dalam rangka konsolidasi tanah di desa kauman Kidul telah termuat dalam Surat pernyataan pelepasan hak atas tanah yang ditanda tangani tanggal 7 November 2017 dengan tanah yang dilepaskan haknya seluas $152.948 \mathrm{~m}^{2}$. Selanjutnya untuk penerimaan pelepasan haknya tercantum dalam surat pernyataan penerimaan pelepasan hak yang ditandatangani oleh Kepala Kantor Pertanahan Kota Salatiga tertanggal 9 November 2017.

Proses penegasan hak atas tanah adalah berdasarkan pendataan awal mengenai riwayat kepemilikan tanah dan data yuridis lainnya. Hasil pendataan yuridis dan pemberian hak atas tanah hasil konsolidasi adalah sebagai berikut: 1) Tanah milik masyarakat yang dikonsolidasikan ditegaskan menjadi hak milik; 2) Tanah negara yang dikuasai masyarakat setelah konsolidasi tanah diberikan hak milik kepada pihak yang telah menguasai tanah;3) Tanah negara yang dikuasai oleh Pemerintah Kota diberikan Hak Pakai dengan tetap mempertahankan luasnya karena sudah tercatat sebagai aset negara.

Pelepasan hak dilakukan oleh semua peserta konsolidasi di depan Kepala Kantor Pertanahan Kota Salatiga disaksikan oleh para saksi. Pelepasan hak langsung diterima oleh Kepala Kantor Pertanahan Kota Salatiga. Pelaksanaan pelepasan hak di Kota Bukittinggi sekaligus dikaitkan dengan pelepasan penguasaan fisik dalam bentuk pernyataan tertulis. Penyampaian pernyataan tersebut dapat dilakukan secara kolektif dan kemudian masingmasing pemegang hak membubuhkan tanda tangannya (Ramadhona, 2017).

Setelah pelepasan hak selesai kemudian dibuat pengajuan permohonan penegasan tanah sebagai obyek konsolidasi tanah ke kanwil BPN Provinsi Jawa Tengah. Penegasan yang dimohon tersebut ditetapkan dengan Keputusan Kepala Kantor Wilayah Badan 
Pertanahan Nasional Provinsi Jawa Tengah. Penegasan tanah ini menjadi dasar pelaksanaan pemindahan desain ke lapang yang sekaligus dilakukan pemasangan patok batas.

Tanah obyek konsolidasi tanah ditegaskan melalui Surat Keputusan Kepala Kantor Wilayah Provinsi Jawa Tengah Nomor 352/KEP-33.11/XII/2017 tanggal 8 Desember 2017 tentang Penegasan Tanah Obyek Konsolidasi Tanah seluas $152.948 \mathrm{~m}^{2}$ di Kota Salatiga, Provinsi Jawa Tengah. Obyek Konsolidasi Tanah yang ditegaskan terdiri dari 115 bidang yang terdiri dari 2 Tanah Negara, 71 Tanah hak milik dan 42 tanah yasan. Konsolidasi tanah merupakan tindakan penataan penguasaan dan pemilikan tanah. Pemilikan tanah tidak lahir dari penataan karena masyarakat telah memiliki tanah sebelumnya. Setelah adanya konsolidasi tanah terdapat perubahan bentuk dan luas bahkan perubahan lokasi. Hal tersebut memiliki konsekuensi terjadinya perubahan batas-batas pemilikan tanah. Atas dasar itu pemberian hak pada tanah-tanah hasil konsolidasi tidak melalui proses pemberian hak tetapi dengan penegasan hak hasil konsolidasi tanah.

Pelaksanaan pemindahan desain konsolidasi tanah ke lapangan dilaksanakan setelah Surat Keputusan Penegasan Tanah obyek Konsolidasi Tanah diterbitkan. Adapun Pemindahan/Pengembalian Batas ini disesuaikan dengan desain yang telah disepakati. Pemindahan desain telah dilaksanakan tanggal 1-7 Desember 2017 sesuai yang tertuang dalam Berita acara pemindahan desain konsolidasi tanah (staking out) ke Lapangan.

Tindak lanjut dari SK Penegasan Tanah Obyek Konsolidasi Tanah yang diterbitkan oleh Kantor Wilayah Provinsi Jawa Tengah adalah penerbitan Surat Keputusan Kepala Kantor Pertanahan Kota Salatiga Nomor 17.113/HM/BPN.33.73/ 2017 tentang Pemberian Hak Milik Atas Nama Jamal dkk (119 Orang) atas 113 bidang tanah, seluas $139.087 \mathrm{~m}^{2}$ dan Surat Keputusan Kepala Kantor Pertanahan Kota Salatiga Nomor 89/HP/ BPN.33.73/2017 tentang Pemberian Hak Atas Tanah Obyek Konsolidasi Tanah Di Kelurahan Kauman Kidul, Kecamatan Sidorejo, Kota Salatiga Atas Nama Pemerintah Kota Salatiga Berkedudukan di Salatiga Atas dua bidang tanah seluas $828 \mathrm{~m}^{2}$. Sedangkan Sertifikat Hak atas Tanah telah dibagikan kepada Peserta Konsolidasi tanah tanggal 30 Desember 2017.

Meskipun tidak ada perubahan letak bidang tanah sawah, tetapi terdapat sumbangan tanah untuk pembangunan infrastruktur. Infrastruktur hasil dari konsolidasi tanah berupa jalan lingkungan dan perbaikan saluran irigasi. Keberadaan jalan lingkungan sangat penting untuk angkutan sarana produksi padi dan hasil panen. Dengan demikian usaha tani tanaman pangan akan lebih efisien dan menambah gairah petani dalam berusaha. Bawono (2018) mengusulkan konsolidasi lahan dikelola sebagai corporate farming oleh 
lembaga pengelola yang profesional tetapi dapat memberikan akses kepada petani untuk melatih diri dan menjadi mandiri dalam berusaha tani.

Kegiatan konsolidasi tanah pada tahun anggaran 2018 di Kota Salatiga berhasil direalisasikan dari target seluruhnya. Pembangunan infrastruktur hasil dari konsolidasi tanah berhasil diwujudkan sebagaimana ditunjukkan pada gambar di bawah ini.

Gambar 3. Pembangunan Hasil Konsolidasi Tanah di Kota Salatiga

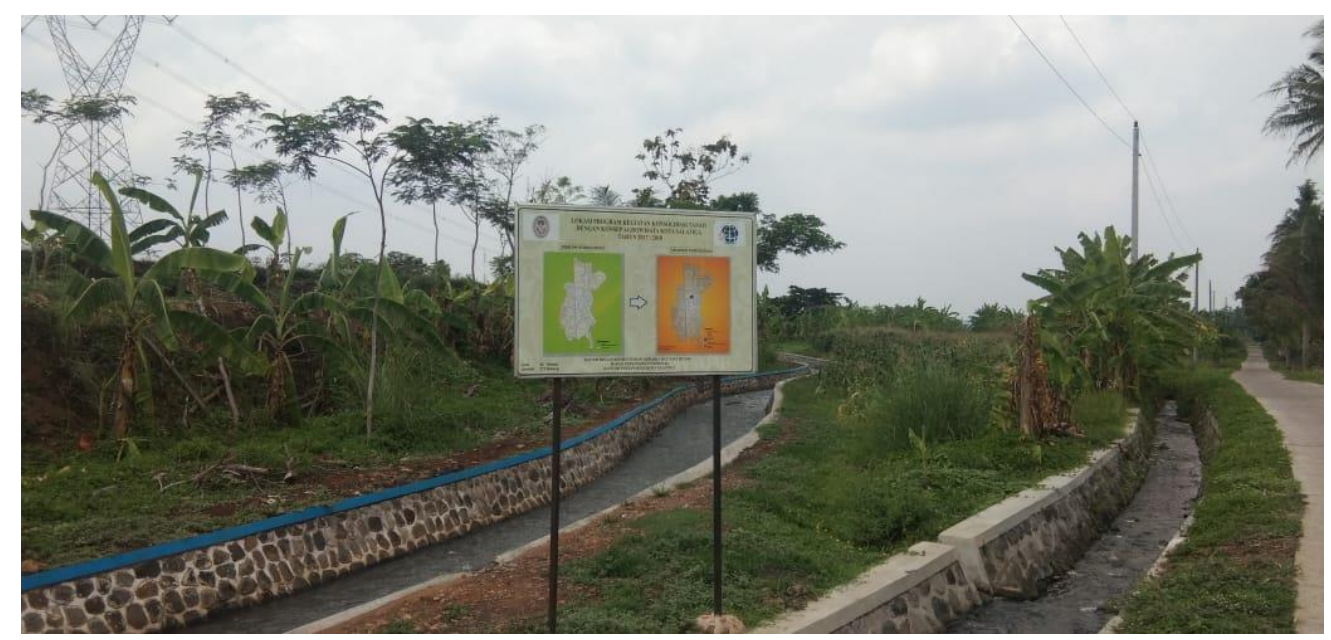

Sumber: Koleksi Penulis, 2019

Setelah kegiatan konsolidasi tanah selesai diselenggarakan dan masyarakat telah memperoleh sertifikat tanah, selanjutnya Pemerintah Kota Salatiga segera membangun sarana yang telah disepakati untuk dibangun dan sekaligus pembangunan kawasan Agrowisata. Tindak lanjut dan pemberian akses terhadap kegiatan konsolidasi tanah ini adalah melalui: Pertama, melalui program pemerintah ditindaklanjuti kegiatan konsolidasi tanah dengan konsep kawasan agrowisata di Kelurahan Kauman Kidul. Program pembangunan yang diimplementasikan diantaranya berupa: a) Perkerasan jalan utama (cor) sumbangan dari DPRD Kota Salatiga; b) Peningkatan irigasi semi teknis menjadi irigasi teknis oleh dinas pertanian Kota Salatiga; c) Bantuan bibit (tanaman dan ikan) dari Dinas Pertanian; d) Pencanangan kawasan sebagai kawasan agrowisata dan perintah pengalokasian penganggaran untuk kawasan agrowisata kepada OPD terkait; e) Fasilitasi dari dinas Pariwisata Kota Salatiga.

Kedua, Kerjasama oleh swasta dan masyarakat peserta konsolidasi tanah secara swadaya. Pihak swasta sudah banyak yang mengajukan untuk turut dalam menindaklanjuti kawasan sebagai kawasan agrowisata. Mereka langsung melakukan survei dan wawancara dengan pihak pengelola (Gapoktan). Tetapi dengan berbagai pertimbangan pihak pengelola belum bersedia melakukan kesepakatan. Salah satu pihak swasta yang secara nyata telah memberikan bantuan adalah Club Mobil di Salatiga yang memberikan bantuan berupa ban bekas sebagai sarana olah raga dan wisata air di Kawasan 
Agrowisata di Kelurahan Kauman Kidul. Peserta konsolidasi tanah secara swadaya juga terus melakukan tindakan guna mengembangkan kawasan. Mereka secara bergotong royong setiap hari Sabtu atau Minggu melakukan kerja bakti membenahi kawasan agar lebih bagus dan berkembang.

Manfaat dari terlaksananya konsolidasi tanah di Kota Salatiga ini, adalah: 1) Terpeliharanya tanah-tanah pertanian yang masih diusahakan oleh petani karena semakin baiknya infrastruktur penunjang usaha tani; 2) Tertatanya bidang-bidang tanah pertanian; 3) Terciptanya lingkungan hidup yang asri dan harmonis sehingga memunculkan kegiatan agrowisata; 4) Terwujudnya infrastruktur yang mendukung agrowisata. Terwujudnya manfaat dari konsolidasi tanah tersebut di atas sejalan dengan hasil konsolidasi yang dikemukakan oleh (Kapoh, 2017) yaitu tertatanya pemilikan dan penggunaan tanah yang mendukung program landreform, terwujudnya keserasian dengan lingkungan hidup sekitar dan terkendalinya harga tanah.

\section{Kesimpulan}

Penyelenggaraan konsolidasi tanah di Kota Salatiga berada pada tanah pertanian yang didominasi oleh tanah sawah dan sebagian kecil tanah pemukiman. Pemilihan lokasi konsolidasi tanah yaitu di Desa Kauman Kidul, Kecamatan Sidorejo berasal dari kajian Potensi Objek Konsolidasi Tanah (POKT). Program konsolidasi tanah dilaksanakan dengan jumlah 115 bidang dan luas 152.948 m2. Penyelenggaraan konsolidasi tanah di lokasi tersebut adalah dengan menata tanah-tanah pertanian milik masyarakat dan penyediaan tanah untuk pembangunan jalan penghubung sehingga mudah diakses untuk mobilisasi sarana produksi pertanian dan angkutan panen. Selain itu masyarakat memperoleh manfaat berupa legalisasi aset tanah dan ditindaklanjuti dengan usaha-usaha pemberdayaan masyarakat terkait dengan agrowisata.

Dasar pembuatan desain adalah peta rincikan dengan kondisi eksisting yang kemudian didesain dengan memasukkan rencana pembangunan infrastruktur berupa jalan dan jaringan irigasi. Pembuatan desain konsolidasi tanah berdasarkan kesepakatan masyarakat termasuk alokasi tanah untuk pembangunan sarana agrowisata. Desain konsolidasi tanah tidak merubah letak bidang tanah, tetapi hanya mengambil sebagian kecil bidang tanah untuk pembangunan infrastruktur dan pelebaran jalan. Dampak konsolidasi tanah terhadap ketahanan pangan adalah terlindunginya tanah-tanah pertanian yang subur dari konversi penggunaan tanah karena masyarakat termotivasi untuk tetap melakukan usaha tani. 


\section{Rekomendasi}

Beberapa saran yang dapat disampaikan terkait dengan kegiatan konsolidasi tanah di Kota Salatiga ini antara lain:

1. Kegiatan konsolidasi tanah harus segera ditindak lanjuti dengan pembangunanpembangunan fisik, sehingga tanah-tanah yang telah diperuntukkan untuk pembangunan infrastruktur tidak diambil kembali oleh pemilik lama

2. Sumbangan tanah untuk pembangunan(STUP) yang berwujud sarana dan prasarana untuk segera diserahkan kepada Pemerintah Kota Salatiga, sehingga dapat ditindaklanjuti pembangunan dan pemeliharaannya

3. Pemerintah Kota dan masyarakat harus bersifat terbuka dan teliti terhadap investor dan pihak-pihak lain (NGO) yang menawarkan bantuan/pembangunan di kawasan lokasi konsolidasi tanah demi kepentingan masyarakat

\section{Daftar Pustaka}

Ariyani, N. D., \& Parsa, I. (2019). Konsolidasi Tanah Sebagai Upaya Meningkatkan Efisiensi dan Produktivitas Pemanfaatan Tanah Perkotaan Secara Optimal. E-Jurnal Universitas Udayana, 1-15. Dipetik Agustus 29, 2021， dari https://ojs.unud.ac.id/index.php/Kerthanegara/article/download/50238/29893.

Bawono, A. T. (2018). Peningkatan Efisiensi Usaha Tani melalui Model Konsolidasi Corporate Farming. Jurnal Perencanaan, 5(1), 13-24.

Candrakirana, I., Sitorus, O., \& Puri, W. H. (2014). Konsolidasi Tanah Perkotaan Sebagai Instrumen Pengadaan Tanah Bagi Kepentingan Umum. Jurnal Bhumi, 40(13), 649662.

Chandra, A. J., \& Diehl, J. A. (2019). Urban agriculture, food security, and development policies in Jakarta: A case study of farming communities at Kalideres - Cengkareng district, West Jakarta. Land Use Policy, 89, 104211. doi:https://doi.org/10.1016/j.landusepol.2019.104211

Du, X., Zhang, X., \& Jin, X. (2018). Assessing the effectiveness of land consolidation for improving agricultural productivity in China. Land Use Policy, 70, 360-367. doi:https://doi.org/10.1016/j.landusepol.2017.10.051

Ekowati, T., Prasetyo, E., \& Eddy, B. T. (2020). Konsolidasi Lahan Pertanian Untuk Meningkatkan Produksi, Produktivitas dan Pendapatan Petani. AGRISOCIONOMICS Jurnal Sosial Ekonomi dan Kebijakan Pertanian, 4(1), 192-205. 
Ekowati, T., Prasetyo, E., \& Eddy, T. B. (2020). Konsolidasi Lahan Pertanian Untuk Meningkatkan Produksi, Produktivitas dan Pendapatan Petani. Agrisocionomics: Jurnal Sosial Ekonomi dan Kebijakan Pertanian, 4(1), 192-205.

Fauzi, R. A., Ichniarsyah, A. N., \& Agustin, H. (2016). Pertanian Perkotaan: Urgensi, Peranan dan Praktik Terbaik. Jurnal Agroteknologi, 10(01), 49-62.

Ishak, M., Nurlinda, I., \& Pujiwati, Y. (2011). Konsolidasi Tanah: Studi Kasus Kecamatan Gedebage,. Jurnal Mimbar, 27(1), 87-96.

Kanwil BPN Provinsi Jawa Tengah. (2016). Potensi Objek Konsolidasi Tanah Kota Salatiga Provinsi Jawa Tengah Tahun 2016. Kanwil BPN Provinsi Jawa Tengah, 1-47.

Kanwil BPN Provinsi Jawa Tengah. (2017). Laporan Konsolidasi Tanah Kota Salatiga. Kanwil BPN Provinsi Jawa Tengah, 1-25.

Kanwil BPN Provinsi Jawa Tengah. (2018). Laporan Akhir Konsolidasi Tanah Kota Salatiga. Kanwil BPN Provinsi Jawa Tengah, 1-26.

Kapoh, S. J. (2017). Pengaturan Konsolidasi Tanah Untuk Pembangunan Perumahan Menurut UU No. 1 Tahun 2011 Tentang Perumahan dan Kawasan Permukiman. Jurnal Lex et Societatis, 5(1), 113-120.

Li, Y., Wu, W., \& Liu, Y. (2018). Land consolidation for rural sustainability in China: Practical reflections and policy implications. Land Use Policy, 74, 137-141. doi:https://doi.org/10.1016/j.landusepol.2017.07.003

Pasaribu, M., \& Istriningsih. (2020). Pengaruh Status Kepemilikan Lahan Terhadap Pendapatan Petani Berlahan Sempit di Kabupaten Indramayu dan Purwakarta. Jurnal Pengkajian dan Pengembangan Teknologi Pertanian, 23(2), 187-198.

Prabowo, H. L. (2017). Region Based Development of Land Consolidation through Land Consolidation Village. Dipresentasikan pada International Conference on Land Consolidation as An Instrument to Support Sustainable Spatial Planning, National Land College, 2017, 83-95.

Pratama, P. I. (2020). Pemanfaatan Tanah Perkotaan Melalui Konsolidasi Tanah. Jurnal Kertha Negara, 8(3), 1-11.

Ramadhona, A. (2017). Pelaksanaan Konsolidasi Tanah Perkotaan Untuk Pembangunan Jalan By Pass di Kota Bukittinggi. Jurnal Cendekia Hukum, 3(1), 73-84.

Siregar, A. M. (2013). Analisis Kesediaan Masyarakat Menerima Program Konsolidasi Tanah Perkotaan Pada Kawasan Permukiman Kumuh Berat. Jurnal Aspirasi, 4(2), 101-117. 
Wijaya, G. P., Silviana, A., \& Triyono. (2016). Praktik Konsolidasi Tanah Perkotaan Sebagai Alternatif Model Pembangunan Wilayah Perkotaan Tanpa Pembebasan Tanah. Diponegoro Law Review, 5(2), 1-18.

Winarso, B. (2012). Dinamika Pola Penguasaan Lahan Sawah di Wilayah Pedesaan di Indonesia. Jurnal Penelitian Pertanian Terapan, 12(3), 137-149.

Yurmansah, \& Mussadun. (2016). Evaluasi Proses Konsolidasi Tanah Kawasan Permukiman Kumuh Bantaran Sungai Kurau Klaster 1 Desa Kurau Berdasarkan Persepsi Masyarakat. Jurnal Pengembangan Wilayah dan Kota, 12(1), 98-11. 